International Journal of Instruction e-ISSN: 1308-1470 • www.e-iji.net

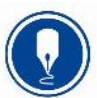

October $2019 \bullet$ Vol.12, No.4

p-ISSN: 1694-609X

pp. $747-766$

Received: 03/02/2019

Revision: 10/07/2019

Accepted: 14/07/2019

OnlineFirst:15/09/2019

\title{
Bilingual English Education: Expectation of Parents who Enrol their Children in Bilingual Primary Schools
}

\author{
Luis Miguel Dos Santos
}

Woosong University, Korea, luismigueldossantos@yahoo.com

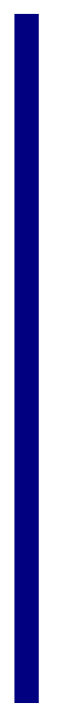

\begin{abstract}
The purpose of this study is to explore the reasons why parents decide to send their children to privately funded primary schools providing a bilingual English language program (BELP) after completion of native language-oriented kindergarten education (i.e. Chinese language). This study was guided by one research question: Why do parents decide to send their children to a primary school with a BELP after the completion of native language-oriented kindergarten education? In order to engage with the nature of the qualitative inquiry, 35 parents were invited to share their understanding and decision of BELP for their children with a semi-structured, face-to-face, and one-on-one interview. Three themes were emerged for reporting: 1. the expectation of advanced English language skills; 2. preparation for international schools, overseas schools, and university admission; and 3. the satisfaction of parents themselves. The findings indicated that parents tend to select programs, which satisfy their own interests instead of being the most appropriate for children. These findings imply that the decision to study in a school with a BELP after native language-oriented kindergarten education is affected by a combination of factors: globalization, advanced English language skills, preparation for further education, career development, and more importantly, the satisfaction of parents.
\end{abstract}

Keywords: bilingualism, bilingual education, English education, foreign language learning, parental influence, primary school

\section{INTRODUCTION}

Due to global economic, social, and political changes, language teaching and learning practices are moving toward bilingualism. English was ranked as the third most spoken language in the world, behind Chinese and Spanish (Dos Santos, 2018). Due to international trading and globalisation, advanced bilingual skills allow people to access better opportunities in various practices, such as education, trading, business, commerce, politics, social issues, and science (Hamid, 2010; Jimenez, García, \& Pearson 2006; Ke,

Citation: Dos Santos, L. M. (2019). Bilingual English Education: Expectation of Parents who Enrol their Children in Bilingual Primary Schools. International Journal of Instruction, 12(4), 747-766. https://doi.org/10.29333/iji.2019.12448a 
2010; Shastry, 2012; Zaharia \& Lolescu, 2009). In order to respond to the demand for bilingual skills, a large number of schools and programs have established various transitional (Chen, 2008; Cobbey, 2007), immersion (Cheng, 2012), bilingual (Dai \& Cheng, 2007; Feng \& Wang, 2007; Feng, 2007), and second language programs (Leibold \& Chen, 2014; Menken, 2015). The purpose of this study is to explore the reasons why parents decide to send their children to privately funded primary schools providing a bilingual English language program (BELP) after completion of native language-oriented kindergarten education (i.e. Chinese language). The term Bilingual, English language program, refers to educational programs aiming to provide a bilingual English language curriculum to students (Baker, 2006; Dennaoui, Nichills, O'Connor, Tarasuik, Kvalsvig, \& Goldfeld, 2016). The number of instructional languages and programs given in each language varies across schools. In the current context, besides Chinese language and literature, in BELPs all subjects are taught in English only. Unlike international schools, where foreign curricula, instruction, and test papers differ from the local education system, BELPs follow the local curriculum and instruction with English as the instructional language.

\section{Significance of the Study}

First, the study has two significances. This study is significant because although the Chinese language is the official and social language, English is the most spoken foreign language in contemporary Chinese society. An advanced level of English is considered to be necessary for the twenty-first-century leader in the workplace. An English language paper is a compulsory part of the current National Higher Education Entrance Examination (NCEE) held annually in China, which students must pass in order to study at the tertiary level (Zhang \& Tsang, 2015). Therefore, in order to respond to students' needs, various academic training and evening programs are provided in preparation for the English language and related exams. In addition to these preparatory programs, privately funded K-12 education institutions have established English-language curricula and educational programs which may respond to this trend (Butler, 2015).

Second, native language curriculum and learning styles may increase the overall achievements and motivations of students. However, in this study, parents decided to send their children to one of the BELP schools which may cause negative outcomes of the learning process. Based on this background, this study tended to explore the reasons why parents want to send their children at one of the BELP schools after the completion of the native curriculum kindergarten (e.g. which may negatively impact the learning process of students). Unlike children who receive native language curriculum and instructions (i.e. Chinese) during their early childhood, Baker (2011) indicated that children might be confused about the language usage and the understanding of between native language (i.e. Chinese) and the targeted language (i.e. English). As a result, when children enter primary schools and secondary school levels, they may not be able to use one single language to communicate and exchange ideas with other people (Garcia, 2009).

In the current academic database, several studies have been conducted to understand the effectiveness and academic developments of learners in China on English language programs (Butler, 2015; Hu, 2008; You \& Dornyei, 2014; Zhang, 2016). However, only 
a few studies (Turner \& Acker, 2017) have addressed the question of why parents decide to send their school-age children to a BELP at a privately funded primary school in China. It is worthwhile to note that BELPs currently tend to provide education to children who have completed their kindergarten education at a native-language school (Feng, Gu, \& Cai, 2016). No primary school students at the first-grade level speak any English.

\section{The Contribution of This Study}

The findings of this study will be beneficial to three groups. First, school administrators and teachers can identify the elements that influence the improvement and substantiality of bilingual English language primary school programs and the possible obstacles that impede them. Second, the study gathered parents' opinions and motivations regarding sending their school-aged children to a bilingual English language primary school. In the other words, interested readers will be beneficial as they can gain the understanding from both sides of the schools (i.e. parents and school administrators). Third, this study is important because it is hoped that its outcomes will enable school communities to work together to develop and enhance the sociolinguistic learning environment to positively influence learning effectiveness at all levels of the school system with a similar urban background. Due to globalization, a large number of primary schools with a similar background have started to establish similar BELPs in order to respond to the demand for English. This study was guided by one research question: Why do parents decide to send their children to a primary school with a BELP after the completion of native language-oriented kindergarten education?

This study outlines a different perspective on the school environment, school leadership, school development, and parents' experiences. It also notes opportunities for other researchers interested in this field to pursue further avenues that may validate the need for changes in bilingual education. The recommendations emerging from this research could potentially help administrators, teachers, students, parents, government officials, and researchers with innovative ideas to enhance the quality of education in China and other regions with similar programs.

\section{LITERATURE REVIEW}

The term bilingual refers to the use of two languages in teaching, primarily to foster learning in students trying to learn a new language. In addition, bilingualism refers to "a term that has been used to describe an attribute of individual children as well as social institutions ... thought of simply as a bivariate function of linguistics proficiency in two languages, under-represents the intricacies of the social setting" (Hakuta \& Garcia, 1989 , p.374). The purpose of bilingual education is to gain abilities in listening comprehension, speaking, reading comprehension, and writing in two languages. As China seeks ways to influence "economic, political, and social reform, and modern science and technology" ( $\mathrm{Su}, 2011, \mathrm{p} .246)$ in the international arena, it is essential to establish bilingual schools and programs.

\section{The Historical Context of Bilingual Education}

Currently, approximately 60 percent of the world's population speaks an additional language besides their mother tongue (Dos Santos, 2018). Based on contemporary and 
historical thinking, bilingualism and multilingualism are norms rather than exceptions. About six centuries ago, the regional language within the Western hemisphere - the primary language for education, political, business, religion, government, and foreign affairs - was Latin. However, at the beginning of the sixteenth century, English, French, and Italian started to gain in importance due to political changes in Europe. As a result, Latin gradually lost its dominance as the European exchange language or Lingua franca in the Western hemisphere (Baugh, 1993; Emerson, 1971; Richards \& Rodgers, 2001). Students were still entitled to study Latin literature and culture, such as Virgil, Ovid, etc., from the seventeenth century to the nineteenth. As of today, English is taught for many different purposes globally due to the colonialism of the United Kingdom and technological growth within English-speaking countries. As a result, English is the primary instructional language for the media curriculum in a large number of countries. In academia, one of the reasons to learn English is the university entrance examination requirement. A high level of English is an entry requirement for much tertiary education in a global market where English gives the user a competitive advantage (Harmer, 1988). In fact, children living in a non-ESL/EFL language environment may have a high risk of delayed language development. Therefore, some institutions have established second language learning communities for students to participate in a second language environment (Scott, Roberts, \& Glennen, 2011)

The purpose of learning English has developed periodically due to the demands of English learners. In general, the purpose of learning the English language has changed from reading comprehension to oral proficiency. This change is also linked to changes and developments in academic theories and concepts (Richards \& Rodgers, 2001). Many of the current theories and concepts are the result of the development of traditional concepts. In other words, many scholars have decided to enhance and improve the traditional theories in order to satisfy contemporary needs and demands of current language learners. Language learning is gradual progress rather than a completed goal; researchers and teachers continue to invest in learning concepts in order to continue their teaching purpose (Kelly, 1969).

\section{Contemporary Bilingual and Language Education in China}

Researchers investigated the learning expectations of teachers and students regarding the future use of English in China. They mentioned the context of globalization and Chinese influence on the global economy, particularly during and after the Beijing Olympic Games in 2008. Their findings show not only that English is a tool for people to access the benefits of globalisation but also that the purposes and demand for English learning are changing rapidly in China. They further supported that researchers believe English language learning is not a completed goal, but instead a continual, gradual process in the global community (Pan \& Block, 2011).

Some scholars examined the dearth of prepared ESL teachers in China and found that a large number of Chinese educational institutions reported difficulties in keeping trained English language teachers because the latter often quit their teaching position for a much better-paid job. Furthermore, teachers in China face heavy workloads and high-stress levels because of the limited funding and provision of resources in bilingual programs 
(Su, 2011). Chinese educational institutions do not yet have any established models for developing bilingual programs, like the "American two-way or Canadian immersion bilingual program" (Su, 2011, p. 266). In addition, few Chinese colleges and universities are ready to provide degree programs that are taught in English. The above factors have created numerous difficulties for the Chinese educational institutions that seek to establish bilingual programs.

English is taught in many private language centres (Dos Santos, 2019b). The researcher conducted a study of the Crazy English training programs in China. The purpose of the Crazy English program is to provide preparatory training for the College English Test (CET) Band 4 certificate for undergraduate students and the CET Band 6 certificate for graduate students, which are required for Chinese university graduation. In addition to the CET program, Crazy English language centres also offer training courses for the Test of English as a Foreign Language (TOEFL), the International English Language Testing System (IELTS), the Graduate Record Examination (GRE), the General Management Admission Test (GMAT), and the Public English Test System (PETS) required by numerous colleges and universities. The purpose of learning English to an advanced level has changed periodically in order to satisfy the needs of students ( $\mathrm{Li}$, 2009).

Researcher affirmed that the purpose of bilingual education programs in China and the United States are not entirely the same. In the United States, some bilingual educational programs seek to help new immigrants to adapt to their new environment. However, bilingual education programs in China exist primarily to prepare students for various examinations, such as TOEFL, CET, IELTS, etc. (Feng, 2005). Butler (2015) examined how parents' socio-economic status, personal behaviors, and personal beliefs influenced their children's motivation in English language learning during their early age at Chinese schools. The result indicated that the expectations of parents have a significant influence on their children's motivation for English language learning due to their socioeconomic status, scores, and social-levels. Parents and children from higher socioeconomic status have the higher chances to encourage their children to spend more time in language learning and even encourage the school English language programmes to adjust the teaching direction in order to satisfy the needs of the children.

Feng (2007) advocated that before the 1970s, bilingual education mainly referred to the language and education programmes for the minorities to understand Chinese Mandarin language for both the usage at schools and daily life. However, due to the globalization and the development of intercultural communication, the bilingual education in China, nowadays, has referred to how to use a foreign language (e.g. English) as the instructional language at the K-12 school environment.

Feng (2007) further indicated that the failure of immersion education. During the 1990s, Hong Kong has returned to mainland China due to the Declaration between China and the United Kingdom. Soon after, researchers (Feng \& Wang, 2007) introduced the British immersion education system to one of the Southern Chinese cities in the Guangdong Province. During that time, the curriculum and instruction of physical education, musical arts, fine arts, and mathematics were instructed in the English 
language. Once the immersion curriculum has been matured, the researchers and piloted schools planned to immerse the school into the English language environment. However, due to the limitations of English language textbooks, teachers, and supporting materials, the immersion directions were failed.

Cobbey (2007) indicated that in China, transitional education mainly focused on how to assist the minority people in understanding the usage of the Chinese language. One of the most common ways is allowing minority people to understand their native language first and transit to Chinese during their K-12 environment. Such transition programmes, however, mainly introduced and conducted in some provinces with minority people, such as Gansu Province. Although the transition programmes are widely used in China nowadays, the application and employment only focus on minority people instead of the majority people in China (Chen, 2008).

Some shared various findings relating to bilingual education (Dos Santos, 2019a). Initially, bilingual education became a requirement for Chinese students to enter colleges and universities, for admission examinations. Next, researcher identified two purposes of bilingual teaching: first, to ensure that Chinese students have the skills to read English articles directly; second, it is a priority because it will ensure that Chinese people have the ability to communicate with foreigners on the international stage ( $\mathrm{Su}$, 2011).

\section{METHOD}

\section{Background of The Site}

In order to protect the identity of the research site, the pseudonym was assigned as the Bilingual Primary School for this study. The study was conducted at private-funded primary school with a BELP in Guangdong Province, China. As of 2018, the enrolment of this primary school was 236. The detailed demography is shown in Table 1. Unlike other immersion schools and private-funded English language-oriented primary schools where mainly serve students with a strong foundation in English language background, Bilingual Primary School tends to accept and enrol $1^{\text {st }}$ graders who had completed their kindergarten education in a native language-oriented kindergarten in order to match with the mission of BELP. Also, Bilingual Primary School does not accept transfer students from other similar primary schools and backgrounds from second grade to sixth grade in order to monitor the overall progression of each individual student.

Table 1

Student Enrolment of the Bilingual Primary School

\begin{tabular}{llll}
\hline Grade & Total Enrolment & Males & Females \\
\hline First & 48 & 28 & 20 \\
Second & 46 & 23 & 23 \\
Third & 40 & 18 & 22 \\
Fourth & 36 & 25 & 11 \\
Fifth & 32 & 12 & 20 \\
Sixth & 34 & 14 & 20 \\
\hline Total & 236 & 120 & 116 \\
\hline
\end{tabular}




\section{Participants}

The participants in this study were 35 parents from the Bilingual Primary School. The snowball sampling method was applied to select parents who have children enrolled in the Bilingual Primary School from first grade to sixth grade (Creswell, 2007). As the researcher was not an employee and board committee of the site, the researcher tended to recruit participants from referral of other parents. The snowball sampling method seems more appropriate as the researcher did not know all of the parents at the school. Also, if the researcher requires an invitation to all parents at the school, the parents may not share the true information to the researcher. As snowball sampling method only requires referral from other parents, parents are willing to share personal difficulties and some in-depth understanding of their stories. As the Chinese government strictly required each family can only have one child prior to 2015 (Feng et al., 2016), none of the parents had more than one child in their family. Therefore, all the parents only have one child in their household.

\section{Data Collection}

The general indutive approach (Thomas, 2006) was employed for the qualitative data collection and analysis. The inductive approach allows the researcher to understand the educational selection problems in China. A combination of a basic qualitative study and the inductive approach is a logical choice for this study because of the flexible design options available to explore the understanding and the sharing of the participants and gain in-depth data (Thomas, 2006). In order to engage with the nature of the qualitative inquiry, parents were invited to share their understanding and decision of BELP for their children with a semi-structured, face-to-face, and one-on-one interview for 20-40 minutes. The interview sections were recorded by a digital recorder and were translated into transcripts for the purpose of data analysis (Tang \& Dos Santos, 2017). Conducting personal interviews enabled the researcher to understand the parents' (a) decision making progress; (b) the expectation of the BELP is hosted; (c) why they decide to send their children to the BELP after the completion of the native language-oriented kindergarten education (Merriam, 2009).

The participants received the invitation letter with the direction of the study, background of the study, the purpose and significance of the study, as well as the interview protocol. During the personal interview sessions, the researcher repeated all the above-mentioned parts as well as the protection of human subjects all participants. After data analysis procedure, the researcher invited each of the participant for the member checking interview for confirmation. As a result, all of the data were confirmed and none of the participants quitted and rejected the result of the data.

\section{Data Analysis}

The open coding (Merriam, 2009) or the first-level coding procedure (Saldana, 2013) was applied in order to capture the initial themes based on the parents' understanding, opinions and sharing. At the first stage, 20-25 first-level themes were categorized. However, in order to outline a more significant finding for the organisation, a further reduction should be conducted. Therefore, the axial coding or the second-level coding 
procedure was applied based on the result of the first-level coding (Saldana, 2013). After the researcher completed the analysis procedure, the researcher sent the related transcripts and data analysis to the participants for the purpose of member checking. After all of the participants viewed and read the information, all of them agreed with the information without any problems. As a result, three major themes were organized and categorized to report for the finding.

\section{Protection of Human Subjects}

Besides the result, findings, and outcome of this study, the protection of human subject must be the priority consideration of this study. Therefore, the researcher conducted all the essential types and procedures of masking all the identifications of parents. Therefore, the name of the parents and students, the city of origins, and ethnicity were masked or provided a pseudonym. In addition, all the agreements, voice recording, transcripts, agreements, identifications, and data information were all locked in a password-protected computer. All the physical items were also locked in a passwordprotected cabinet. Besides the researcher, no one could have access to all the related materials for this study (Seidman, 2006).

\section{The Usage of Language}

In fact, as this study was conducted in China, Chinese language was the primary language tool for the interview. Although the parents were welcomed to use English to communicate with the researcher, the parents tended to share their interview section in the Chinese language as a second language or additional language may not able to express the in-depth understanding. In order to report this study on an international channel, all the Chinese interview transcripts were translated from Chinese to English before the open coding procedure.

\section{FINDINGS}

Although the detailed reasons for each parent's understanding, decision-making process, opinions, and purposes differed, core and similar concepts were categorized for reporting. After careful data analysis, three themes were emerged for reporting: 1. the expectation of advanced English language skills; 2. preparation for international schools, overseas schools, and university admission; and 3. the satisfaction of parents themselves.

\section{The Expectation of Advanced English Language Skills}

When talking about learning a foreign language in China, most people refer to English. During the past century, due to the rapid development of technology and business opportunities in anglophone countries, gaining an advanced level of English could be considered as a means of achievement. Therefore, most parents in their twenties and thirties usually believed that their children should achieve an advanced level of English in early childhood in order to become successful professionals in the twenty-first century. 
Similarly, all of the parents expressed the opinion that gaining advanced English language skills was a priority for their children's enrolment in further education. Twenty-seven parents stated that the selection of a BELP was a milestone in their children's preparation for various national and international exams. Parent \#7 said "if my son can learn English at an early age, he will be well prepared for different exams in his teenage years." Parent \#1 expressed a similar idea "if my child is well-prepared for TOEFL at a young age, I guess he will be able to achieve a good score in TOEFL in secondary school."

Some parents stated that China is a test-oriented country and that exams are the key consideration for university admission and job opportunities. As parent \#12 said "in China, everything is about test scores. Teachers need a license, doctors need a license, and even masseurs need a license. My child needs to be well-prepared to become a good test-taker, particularly in the English language."

Similarly, parent \#4 said "even if I want to become a real estate agent, I need to take an all-day exam. If my child does not have this test preparation, how will he be able to take exams in the future? ... he needs to be well-prepared with English language skills first, and then English language test-taking skills."

Parent \#15 expressed the same idea:

My daughter needs to take the TOEFL Primary, TOEFL Junior, and TOEFL. The exam board designed these exams to students must have their purposes. English is the second most spoken language behind Chinese. I expect her to have good English and Chinese skills in her teenage years.

Therefore, some parents believe advanced English language skills equip their children for test-taking skills for further education and university admission exams. Some other parents believed that mastery of both Chinese and English is the key for twenty-firstcentury professionals to communicate with the global citizen. Therefore, both Chinese and English language skills should be learned from childhood. Parent \# 18 said:

The English language has a historical international reputation ... If Chinese children can speak both languages, they will have better job opportunities at the international level.

Parent \#13 also spoke about the global citizen:

a lot of people talk about the idea of a "global citizen." In the near future, China will become a global leader in business and finance. Since my child can speak Chinese already, I must teach him to speak English ... to go into the world for opportunities ...

Parent \#26 added:

My child can speak both Cantonese and Mandarin because of mother tongue and kindergarten education. Now is a reasonable time for him to learn a new language in childhood. If children can learn a language at an early age, they can master it without many difficulties. Also, they do not need to think much about different subjects, such as mathematics, science, etc. 
In conclusion, most of the parents believed that attending a BELP at primary school level would help their children to gain advanced second language skills during childhood, to obtain advanced test-taking skills, and to become a well-prepared global citizen in the future.

\section{Preparation for International Schools, Overseas Schools, and Universities}

Studying overseas has become a trend for K-12 students and secondary school graduates. More than 20 parents stated that attending a BELP at primary school level is early preparation for their children's attendance of international secondary schools and international universities. Twenty-five parents believed that a BELP at primary school level is a transitional step to attending international schools in China or privately funded secondary schools overseas. Parent \#3 said:

There are several well-known international secondary schools ... If possible, I would like to send my child to one of these after primary school. But in order to gain admission to these schools ... children are required to have advanced skills in English.

Parent \#6 had a similar desire:

There are five or six well-known international schools in Guangdong Province. Even if the family has enough resources, the English and other subject scores are the primary considerations of their admission decision. This BELP can help me to overcome the problem in English. My husband and I will handle my child's musical and sports abilities.

On the other hand, Parents \#17, \#28, and \#29 thought that they would send their children to different non-mainland Chinese locations, such as Hong Kong, Britain, and the United States. Parent \#17 said:

My family sought Hong Kong residency several years ago so that my child could have better educational opportunities. But if my child can only speak Mandarin and has no English, it will be difficult to enter Hong Kong society. As our plan is to apply to international schools in Hong Kong, it is necessary to start this BELP at primary school.

Parent \#28 shared his intention to send his child to Britain after $6^{\text {th }}$ grade "Britain has a better education in terms of freedom of learning, physical facilities, learning the background, etc. I want my child to have a fresh start near his grandparents in childhood." Parent \#29 had similar ideas "if my child goes to the United States without a solid grounding in English, then he may miss a year of meaningful interactions with peers and classmates."

Based on the comments, a large number of parents aimed to send their children to overseas and international schools and universities after secondary school graduation. Several parents indicated that in order to achieve better scores and university admission decisions, advanced language proficiency and international perspectives are essential. Therefore, such motives increase the interests of why parents decided to send their children to BELP schools after kindergarten education. 
Similarly, 24 other parents advocated that the BELP could be a preparatory platform for their children to take various international exams, such as the International Baccalaureate Exam (IB Exam), General Certificate of Education (GCE), Scholastic Aptitude Test (SAT), etc. Parent \#10 said "my child will eventually go to the United States for either secondary school or university. I want him to get good preparation in China first." Parent \#11 had a similar idea "my son is still very young; I do not want him to go to the United Kingdom at such a young age. But if he can get a similar grounding in English in China at a young age, I would like to send him to these schools." Parent \#14 added:

BELP is an excellent way to prepare our children for the British education system at the secondary school level. My daughter needs to take the International Baccalaureate exams in $12^{\text {th }}$ grade. If she can make a good start at the primary school level, she will be prepared for the IB exams in the future. At least she will be able to understand the language and lessons at secondary school.

Parent \#5 added:

I am not sure which country my child will go to university, but my goal is to provide the best education for her. I have not decided which country she should go to in the future ... Australia, the United Kingdom, and the United States are three of my choices. But excellent English skills are essential for both SAT and GCE exams for sure.

On the other hand, two participants considered the BELP to be a milestone for the preparation of their children for the NCEE for university admission in China. Parent \#31 said that "The National Higher Education Entrance Examination attracts more than 9 million students each year. In order to get into a top-tier university in China, one must have excellent scores, particularly in English." Parent \#23 added that:

The NCEE is accepted by a large number of Australian universities, particularly the English language score. If my child can achieve a good score in this exam, he can go to either a Chinese university or an Australian university in the future. In order to achieve a good score, I need to help with the preparation.

In conclusion, it is worth noting that most of the parents had decided to enrol their children on a BELP to prepare for examinations, both Chinese and international. However, only a few thoughts that a BELP could improve the language skills of their children.

\section{The Satisfaction of Parents Themselves}

Parents and guardians should have the right to decide which school is appropriate for their children. However, none of the parents here had consulted with their children about schooling decisions. In other words, none had asked their children whether they would like to attend a BELP at primary school level after Chinese language-oriented kindergarten. Based on the interviews, the researcher noted that 28 of the participants talked about sending their children to a BELP, mainly for their own satisfaction, instead of negotiation between parents and children. 
Some parents said that the idea to send their children to a BELP was based on the negative experiences of their nieces and nephews. Parent \#30 said:

My child's cousin went to both Chinese kindergarten and primary school. He cannot speak proper English at all. Even if he is good in history and social science, how can he become a successful person in the future without good English?

It is worth to note that comparisons between peers are not uncommon in Chinese society. In the term of satisfaction of parents themselves, although some parents understand such BELP schools may not be the best match for their children, parents tended to enrol their children into the program due to their personal satisfaction and self-esteem. Also, Parent \#8 said something similar:

My son's cousin has just taken the SAT and TOEFL exams in the summer. His cousin went to a Chinese language-oriented secondary school. He and his parents had a plan to apply to American universities. However, based on the test scores and his English, he was only accepted by two community colleges for preparatory courses. I cannot accept such a future for my child. So I must send him to an English language-oriented school.

Parent \#9 added:

My husband and I plan to send our son to the United States after junior high school. One of our concerns is the American accent. My son's cousin also plans to go to California for university after high school. When I talked to her, I noted that her accent is very bad. If my son also had such a strong Chinese accent or poor English...I just don't like it.

Another factor is that some parents planned to send their children to overseas universities after secondary school education in China. As Chinese language is considered as an elective subject for university admission requirements, parents decided to send their children to BELP schools after the comparisons and observations from other similar parents, families, and peers.

Besides the negative experiences of relatives, the personal satisfaction of parents themselves is a significant factor. Five of the participants expressed that their decision to send their children to a BELP was based on the importance of standing out from others. Some parents stated that the idea of having a child who can speak a foreign language perfectly could satisfy their demands. Parent \#32 said "I think it would be so cool if my child could talk to me in English." Parent \#7 added "I just want to have a child who can talk to me in English. There are Chinese-speaking children all over the city. They're nothing special." Parent \#2 stated that having an outstanding family was her goal for raising her child:

His kindergarten has an agreement with four different primary schools in our city. But all four are Chinese language-oriented schools. More than $90 \%$ of his classmates have transferred to one of these four, but I just do not want my child to have a normal life. Even if he wants to go to primary school with his best friend, I still need him to go to this English-oriented school.

Parent \#11 said something similar: 
I would like my child to be able to communicate with foreigners in the future. I also want my child to be able to operate a business in international locations. I think having a child who can speak English perfectly is very cool. So, I decided to send my child to this school.

Parent \#16 also liked the idea of having a child who can speak English perfectly:

There are millions of Chinese students and residents in China. I just do not want my child to be one of the millions. Do you think it is cool to have an outstanding child if you can spend some resources on her?

In conclusion, it is surprising that some of the participants wanted to send their children to a BELP mainly to satisfy their own interests rather than for their children to learn. Some participants even stated that comparing themselves to their relatives was one of the primary reasons for selecting schools for their children.

\section{DISCUSSION}

The purpose of this study is to explore why Chinese parents decide to send their children to a primary school with a BELP after the completion of native language-oriented kindergarten education. Regardless of their social status, parents are always thought to try their best to seek appropriate education for their children. However, the findings of this study indicate that parents tend to select educational programs which satisfy their own demands and interests instead of being the most appropriate for their children, particularly when comparing children with similar backgrounds (Butler, 2015). The current finding further echoed the relationship between globalization (i.e. business development) and English language learning in China. According to Cobbey (2007), due to the rapid development of the contemporary Chinese society and economy, a large number of parents who can afford private schooling always send their children to private schools and one of the English-oriented schools. Due to the significant tuition fees and supplementary costs, parents expressed the higher expectations of their school selection (Dos Santos, 2019b). The parents here also had relatively high expectations of advanced English language skills for further education and career development. These findings imply that the decision to study in a primary school with a BELP after native languageoriented kindergarten education is affected by a combination of factors: globalization, advanced English language skills, preparation for further education, career development, and more importantly, the personal satisfaction of parents (Curdt-Christiansen \& Wang, 2018; Sun et al., 2016).

First, the findings revealed significant connections between expectations of advanced English language skills and the decision to enrol in BELP primary schools. Unlike other transitional (Chen, 2008; Cobbey, 2007), immersion (Cheng, 2012), and second language (Leibold \& Chen, 2014; Menken, 2015) programs, the current BELP tends to focus and develop based on the recommendations of second language programs. The curriculum and planning also echoed the advantages of how to emerge Chinese language speakers and students to adopt the English language learning pathways with the appropriate instructions and directions from the previous literature (Leibold \& Chen, 2014; Menken, 2015). 
More than two-thirds of the parents indicated that advanced English language skills were one of the essential factors for preparing their children to be twenty-first-century leaders. English has been part of the K-12 curriculum for more than three decades (Ke, 2010). In early 2001, the Chinese Ministry of Education indicated that English was one of the essential subjects for the current curriculum reforms and development. From the fall of 2001, public schools at city and county level were required to establish English courses. From the fall of 2002, schools at town and village level were required to establish English courses from $3^{\text {rd }}$ grade. As a result, it further echoed the finding of (Feng, 2007; Feng \& Wang, 2007) Chinese children could learn English from an early age. However, as the importance of English has grown, school admissions offices, employers, parents, and even school administrators have become increasingly concerned about English language achievement (Qi, 2016). For example, Parent \#1 suggested that "no matter which places and cities in China and Asia, both Chinese and English are required for $21^{\text {st }}$-century leaders." In a large nation with many qualified students, the assessment of English tends to be conducted by formative tests and exams. Various national and international exams and preparatory courses have been established to boost scores and to satisfy the demands of the market (Dos Santos, 2019b; Pan \& Block, 2011).

Second, given that Chinese people need advanced English for their education and career development, it is assumed that parents who can afford private schooling tend to send their children to BELP primary schools due to the trend toward English in contemporary Chinese society (Wang, 2015). Under these circumstances, in the current study, a large number of parents expressed their concerns about how the BELP may prepare their children to satisfy the needs of the current social demand. For example, Parent \#11 advocated that "the BELP is a platform for my children for globalization in the future...in China and even the world." Parents \#15 further with the idea about "I would try my best to provide the best schooling to my child." In short, the expectation of Chinese parents is increasing due to global challenging and globalization. It further echoed the previous literature and researchers (Hu, 2008; Ke, 2010; Menken, 2015) how English language programs and English-oriented schools are highly selective in contemporary Chinese society.

Third, according to previous studies, many Chinese secondary school graduates finish their education at an overseas university, such as in the United States, the United Kingdom, or Australia (Dos Santos, 2018). In addition, Chinese students in the United States tend to enrol at top-tier research-based universities due to the emphasis on competition and perfectionism in their cultural background. Within such a competitive educational environment, Chinese parents tend to provide academic training for their children from an early age (Tao \& Gao, 2018). The current finding echoed the future expectations of Chinese parents and their children with the reports of (Feng, 2005) about the bilingualism and the parallel conceptions in China. In fact, it has been found that many Chinese parents tend to send their children to BELPs and schools with an English curriculum in the interests of further education in international schools and universities (Feng, 2007). Therefore, Chinese parents, especially those who can afford private K-12 schooling, send their children to BELP schools to prepare them for their later education 
and career development (Bodycott \& Lai, 2017). In short, the directions of bilingual education in China have been changed due to the demands of contemporary Chinese parents. Almost a century ago, most of the bilingual and second language programs in China tended to focus on language usage and conversational skills for minority people in China. However, researchers (Feng, 2005; Feng, 2007; Feng \& Wang, 2007; Ke, 2010) argued that English language programs and other related bilingual and second language programs in China do not only provide the benefits and advantages to minority people but all Chinese people and students. In short, bilingual, BELP, and other related second language programs in China have been developed and changed its direction from minority-oriented to the means of all Chinese residents. The current study further explored the contemporary Chinese parents' expectations and understanding of the BELP for their children (Ke, 2010)

Fourth, besides environmental factors (e.g. the trend of English use and the national curricular reforms and development), and educational and career competition (e.g. expectations of employers and university admissions offices), the findings reveal a significant connection between the satisfaction of parents and BELP enrolment (Wang, 2015). It is worth noting that Chinese parents like to compare their children to others with similar backgrounds (Bi \& Oyserman, 2015). According to Pan \& Block (2011), the Beijing Olympias Games 2008 served as the milestone of the motivation of English language in China. In order to seek career opportunities for such international competitions and games, Chinese parents always force their children and even themselves to learn English for future career development (Sun et al., 2016). More than half of the parents here stated that Chinese children who do not have advanced English are discriminated against. Enrolling on BELP programs may avoid such discrimination due to accent and grammatical errors. Also, some parents indicated that children who can communicate in English in daily life increase their self-satisfaction and increase their social roles in Chinese society. Several parents described the idea of their children communicating with advanced English as "cool." The sharing and finding of this research further echoed the points from Butler (2015) how Chinese parents described their understanding and motivation for learning English and the language acquisition of their children.

Surprisingly, none of the parents considered BELP enrolment from their children's perspective. In other words, all the parents decided to send their children to their preferred school for their own personal satisfaction. Although this study has not collected opinions or academic scores from the children themselves, it is assumed that some children may not want to change the language of instruction and curriculum due to their motivation to learn. Several parents also said that even if their children disliked the BELP and English-language instruction, they forced them to continue for their own satisfaction (Bi \& Oyserman, 2015).

\section{LIMITATIONS, FUTURE DIRECTIONS, CONCLUSIONS}

This study has three limitations. First, it focused on Chinese parents' perspective on sending their children to a primary school with a BELP after the completion of native language-oriented kindergarten education. Data were gathered from personal interviews. 
The researcher could not incorporate the children's perspective on decisions regarding their schooling. Although parents have the right to select the most appropriate school for their children, children's opinions and understanding should be taken into account.

Second, further interviews with BELP school administrators and principals might be incorporated. BELP programs are highly popular in the current Chinese education system, particularly in private K-12 schools. There may be meaningful differences in the opinions of school administrators and parents depending on the sociocultural context.

Third, besides BELP and English-language curriculum and instruction, different types of curriculum and instruction, such as martial arts, STEM, vocational, and design primary and secondary schools, are established in order to respond to the market demands in the educational field. Further research could be conducted into different individual curricula.

Enhancing and developing high-quality and effective curriculum plans for non-native speakers of English require long-term planning and reforms. In this study, the researcher attempted to understand the reasons for BELP enrolment. Based on the findings, the researcher attempted to provide a picture of the overall situation and recommendations to school administrators and parents to allocate appropriate resources, reform the curriculum and instruction, and enhance the schooling of young citizens. The findings indicate that many parents are concerned about the education and career development of their children due to the rapidly changing world and globalization. The BELP provides an advantage (e.g. English language training) to their children.

Also, due to the reasons of globalization, a large number of Chinese parents decided to send their children to overseas universities after secondary school graduation. Many parents also advocated that the BELP schools are good channels for exam-training. It is worth to note that some Chinese parents ranked testing scores and outcomes of achievements higher than knowledge acquisitions. In other words, some Chinese parents strongly believed outstanding scores and university admission decisions are more important than knowledge learning. This is one of the most interesting factors in this study.

Furthermore, some parents also argued the comparisons among other children, peers, families, and groups are not uncommon in China. Chinese parents will gain higher personal satisfaction and self-esteem if their children gain better scores and academic achievement. Surprisingly, almost none of the parents advocated learning process and knowledge acquisition are as important as scores and academic achievement. It is worth to note that China is a test-oriented country where people mainly aim for exams and achievements. However, the applications and skills employments are not as important as the scores and academic achievement. Therefore, based on the social environment, social influence, and parents' decision due to the social environment, Chinese youth tend to exercise such competitions during their early childhood.

Nevertheless, today's Chinese youth are equipped for diversity and multicultural perspectives for the twenty-first century. By supporting their adjustment to the K-12 education environment, primary schools assist children to access more excellent 
opportunities in their social, academic, and career development. K-12 schools need to identify and implement specific teaching and learning strategies to help facilitate appropriate curricula and enrolment planning. As for the relationship between parents and schools, parents, school administrators, and students will benefit if all parties understand each other's expectations.

\section{ACKNOWLEDGE}

The research received funding from Woosong University Academic Research Funding 2019.

\section{REFERENCES}

Baker, C. (2006). Foundations of bilingual education and bilingualism. Clevedon, UK: Multilingual Matters.

Baugh, A. (1993). A history of the English language. Englewood Cliffs, N.J.: PrenticeHall.

Bi, C., \& Oyserman, D. (2015). Left behind or moving forward? Effects of possible selves and strategies to attain them among rural Chinese children. Journal of Adolescence, 44, 245-258. https://doi.org/10.1016/j.adolescence.2015.08.004.

Bodycott, P.; Lai, A. (2017). The role of Chinese parents in decisions about overseas study. In H. Mihut, G. Altbach, \& P. Wit (Eds.), Understanding Higher Education Internationalization. Global Perspectives on Higher Education (pp. 197-201). Rotterdam: Sense Publishers.

Butler, Y. (2015). Parental factors in children's motivation for learning English: A case in China. Research Paper in Education, 30(2), 164-191. https://doi.org/10.1080/02671522.2014.891643.

Chen, Y. (2008). Muslim Uyghur students in a Chinese boarding school: Social recapitalization as a response to ethnic integration. New York: Lexington Press.

Cheng, L. (2012). English immersion schools in China: Evidence from students and teachers. Journal of Multilingual and Multicultural Development, 33(4), 379-391.

Cobbey, H. (2007). Challenges and prospects of minority bilingual education in China: An analysis of four projects. In A. Feng (Eds.), Bilingual education in China. Practices, policies and concepts (pp.182-199). Clevedon: Multilingual Matters.

Creswell, J. W. (2007). Qualitative inquiry and research design: Choosing among five approaches. Thousand Oaks, CA: SAGE Publications.

Curdt-Christiansen, X. L., \& Wang, W. (2018). Parents as agents of multilingual education: family language planning in China. Language, Culture and Curriculum, 31(3), 235-254. https://doi.org/10.1080/07908318.2018.1504394. 
Dai, Q., \& Cheng, Y. (2007). Typology of bilingualism and bilingual education in Chinese minority nationality regions. In A. Feng (Eds.), Bilingual education in China. Practices, policies and concepts (pp.75-93). Clevedon: Multilingual Matters.

Dennaoui, K., Nichills, R., O'Connor, M., Tarasuik, J., Kvalsvig, A., \& Goldfeld, S. (2016). The English proficiency and academic language skills of Australian bilingual children during the primary school years. International Journal of Speech-Language Pathology, 18(2), 157-165. https://doi.org/10.3109/17549507.2015.1060526.

Dos Santos, L. M. (2018). Foreign language learning beyond English: The opportunities of one belt, one read (OBOR) Initiative. In N. Islam (Eds.), Silk road to belt road (pp. 175-189). Singapore: Springer.

Dos Santos, L. M. (2019a). English language learning for engineering students: Application of a visual-only video teaching strategy. Global Journal of Engineering Education, 21(1), 37-44.

Dos Santos, L. M. (2019b). The relationship between teachers' beliefs, teachers' behaviors, and teachers' professional development: A literature review. International Journal of Education and Practice, 7(1), 10-18. https://doi.org/10.18488/journal.61.2019.71.10.18.

Emerson, O. (1971). The history of the English language. Ann Arbor, M.I.: Plutarch Press.

Feng, A. (2005). Bilingualism for the minor or the major? An evaluative analysis of parallel conceptions in China. International Journal of Bilingual Education and Bilingualism, 8(6), 529-551.

Feng, Y. (2005). The similarities and differences between the goals of bilingual education in China and the United States. US-China Education Review, 3(1), 48-51.

Feng, A. (2007). Intercultural space for bilingual education. In A. Feng (Eds.), Bilingual education in China: Practices, policies and concepts (pp.259-286). Clevedon: Multilingual Matters.

Feng, Z., \& Wang, J. (2007). Integrated English: A bilingual teaching model in Southern China. In A. Feng (Eds.), Bilingual education in China: Practices, policies and concepts (pp.147-165). Clevedon: Multilingual Matters.

Feng, W., Gu, B., \& Cai, Y. (2016). The end of China's one-child policy. Studies in Family Planning, 47(1), 83-86. https://doi.org/10.1111/j.1728-4465.2016.00052.x

Garcia, O. (2009). Bilingual education in the $21^{\text {st }}$ century: A global perspective. Malden, MA: Wiley-Blackwell.

Hakuta, K., \& Garcia, E. E. (1989). Bilingualism and education. American Psychologist, 44(2), 374-379. https://doi.org/10.1037/0003-066X.44.2.374. 
Hamid, M. (2010). Globalisation, English for everyone and English teacher capacity: language policy discourses and realities in Bangladesh. Current Issues in Language Planning, 11(4), 289-310.

Harmer, J. (1988). The practice of English language teaching. Essex, UK: Pearson.

$\mathrm{Hu}$, G. (2008). The misleading academic discourse on Chinese-English bilingual education in China. Review of Educational Research, 78(2), 195-231. https://doi.org/10.3102/0034654307313406.

Jimenez , R., García, G., \& Pearson, P. (1996). The reading strategies of bilingual Latina/o students who are successful English readers: Opportunities and obstacles. Reading Research Quarterly, 31(1), 90-112. https://doi.org/10.1598/RRQ.31.1.5.

Ke, I. (2010). Global English and world culture: A study of Taiwanese university students' worldviews and conceptions of English. Journal of English as an International Language, 5(1), 81-100.

Kelly, L. (1969). Centuries of language teaching. Rowley, MA: Newbury House.

Li, J. (2009). From classroom to imagined community: A study of three learners of crazy English in China. An Australian Journal of TESOL, 24(1), 49-67.

Leibold, J., \& Chen, Y. (2014). Introduction: Minority education in China. In J. Leibold, $\&$ Y. Chen (Eds), Minority education in China: Balancing unity and diversity in an era of critical pluralism (pp.1-24). Hong Kong: Hong Kong University Press.

Menken, K. (2015). Principals as linchpins in bilingual education: The need for prepared school leaders. International Journal of Bilingual Education and Bilingualism, 18(6), 676-697. https://doi.org/10.1080/13670050.2014.937390.

Merriam, S. B. (2009). Qualitative Research: A Guide to Design and Implementation. San Francisco, CA: Jossey Bass.

Qi, G. Y. (2016). The importance of English in primary school education in China: perceptions of students. Multilingual Education, 6(1), 1-18. https://doi.org/10.1186/s13616-016-0026-0.

Pan, L., \& Block, D. (2011). English as a "global language" in China: An investigation into learners' and teachers' language beliefs. System, 39(3), 391-402. https://doi.org/10.1016/j.system.2011.07.011

Richards, J.; Rodgers, T. (2001). Approaches and methods in language teaching. Cambridge, UK: Cambridge University Press.

Saldana, J. (2013). The coding manual for qualitative researchers. Los Angeles, CA: Sage Publications.

Scott, K. A., Roberts, J. A., \& Glennen, S. (2011). How well do children who are internationally adopted acquire language? A meta-analysis. Journal of Speech, 
Language, and Hearing Research, 54(4), 1153-1169. https://doi.org/10.1044/10924388(2010/10-0075).

Seidman, I. (2006). Interviewing as qualitative research: A guide for researchers in education and the social sciences. New York, NY: Teachers College Press.

Shastry, G. (2012). Human capital response to globalization. Journal of Human Resources, 47(2), 287-330.

$\mathrm{Su}$, B. (2011). On the bilingual teaching reform in China: A look into Sino-U.S bilingual education. International Journal of English Linguistics, 1(2), 264-268. https://doi.org/10.5539/ijel.v1n2p264.

Sun, H., Steinkrauss, R., Tendeiro, J., \& De Bot, K. (2016). Individual differences in very young children's English acquisition in China: Internal and external factors. Bilingualism: Language and Cognition, 19(3), 550-566. https://doi.org/10.1017/S1366728915000243.

Tang, K. H., \& Dos Santos, L. M. (2017). A brief discussion and application of interpretative phenomenological analysis in the field of health science and public health. International Journal of Learning and Development, 7(3), 123-132. https://doi.org/10.5296/ijld.v7i3.11494.

Tao, J., \& Gao, X.. (2018). Identity constructions of ESP teachers in a Chinese university. English for Specific Purposes, 49, 1-13. https://doi.org/10.1016/j.esp.2017.09.003.

Turner, Y., \& Acker, A. (2017). Education in the new China: Shaping ideas at work. London, UK: Routledge.

Wang, W. (2015). Teaching English as an international language in China: Investigating university teachers' and students' attitudes towards China English. System, 53, 60-72. https://doi.org/10.1016/j.system.2015.06.008.

You, C., \& Dornyei, Z. (2014). Language learning motivation in China: Results of a large-scale stratified survey. Applied Linguistics, 37(4), 495-519. https://doi.org/10.1093/applin/amu046.

Zaharia, A. \& Lolescu, R. (2009). Globalization of English as a corporate language. Annals of the University of Petrosani Economics, 9(4), 329-334.

Zhang, J. (2016). Language attitudes and identities in multilingual China: A linguistic ethnography. International Journal of Bilingual Education and Bilingualism, 19(4), 471-474. https://doi.org/10.1080/13670050.2015.1055934.

Zhang, Y., \& Tsang, M. (2015). Gender gap in the national college entrance exam performance in China: A case study of a typical Chinese municipality. Asia Pacific Education Review, 16(1), 27-36. https://doi.org/10.1007/s12564-014-9351-8. 